\title{
Effect of Copper on Growth Characteristics and Disease Control of the Recently Introduced Guignardia citricarpa on Citrus in Florida
}

\author{
Katherine E. M. Hendricks ${ }^{1}$, Ryan S. Donahoo ${ }^{1}$, Pamela D. Roberts ${ }^{1 *}$, Mary C. Christman ${ }^{2}$ \\ ${ }^{1}$ Southwest Florida Research and Education Center, University of Florida-IFAS, Immokalee, USA; ${ }^{2}$ MCC Statistical Consulting LLC, \\ Gainesville, USA. \\ Email: ${ }^{*}$ pdr@ufl.edu
}

Received December $20^{\text {th }}, 2012$; revised January $22^{\text {nd }}, 2013$; accepted January $30^{\text {th }}, 2013$

\begin{abstract}
Guignardia citricarpa, the plant pathogenic fungus that causes citrus black spot, was recently introduced into the United States. The development of this disease in the presence of multiple applications of copper per year to manage citrus canker warrants an investigation into the effects of copper on growth of isolates of G. citricarpa from citrus in Florida. Guignardia citricarpa and G. mangiferae isolates, confirmed by internal transcribed spacer (ITS) sequencing of ribosomal DNA and DNA homology, were inoculated on non-amended media and media amended with 50 and 500 $\mu \mathrm{g} \cdot \mathrm{ml}^{-1}$ copper sulfate. Radial colony growth was assessed over a 26 to 59 day period. Copper reduced the growth of $G$. citricarpa isolates in media amended with $500 \mu \mathrm{g} \cdot \mathrm{ml}^{-1}$ copper but had variable effects on radial growth in media amended with $50 \mu \mathrm{g} \cdot \mathrm{ml}^{-1}$ copper. There was little effect of copper on the in vitro growth of G. mangiferae isolates. Field application of copper with and without an adjuvant for the control of citrus black spot was undertaken in a commercial grove in Florida in 2011. Spray applications were made on a $23.3 \pm 4.7$ day interval and fruit accessed between December 2011 and March 2012 for black spot symptoms. Copper failed to reduce the proportion of fruit exhibiting symptoms compared to that of the controls.
\end{abstract}

Keywords: Copper Tolerance; Citrus Black Spot; Guignardia mangiferae; Saprophyte; Citrus x sinensis

\section{Introduction}

Guignardia citricarpa (Anamorph: Phyllosticta citricarpa) is the causal agent of Citrus Black Spot (CBS) and is capable of infecting all economically important varieties of citrus $[1,2]$. The disease was initially described more than 100 years ago in New South Wales, Australia, and has subsequently been found in Africa, Asia, South America, and New Zealand [3-5]. Guignardia citricarpa was observed for the first time in North America when orange fruit exhibiting lesions typical of CSB were found in Southwest Florida grove and tested positive for the CBS fungal pathogen [6]. Guignardia citricarpa does not affect the quality of the fruit however in areas where the disease is endemic untreated groves have been reported to experience up to $80 \%$ yield loss due to fruit drop [2]. In 2010, United States citrus export was valued at $\$ 2.9$ billion, with $\$ 380.8$ million attributed to fresh oranges [7]. Florida is the largest producer of oranges $(69 \%)$ in the US, producing 6.4 million tons in 2010 , followed by California, Arizona and Texas [7]. The potential eco-

*Corresponding author. nomic losses due to the disease either through fruit drop or rejection for the fresh market because of the unsightly lesions or potential quarantine of fruit sales to other citrus production regions could be estimated in the hundreds of millions of US dollars.

While the introduction of G. citricarpa into Florida is recent, the closely related G. mangiferae was first documented causing black spot in mango in the 1970s [8]. To date, G. citricarpa has not been reported affecting noncitrus hosts, unlike G. mangiferae which has been described on a variety of non-citrus hosts worldwide including mango (Mangifera indica) in Ghana, cycads from South Africa and Florida, and Hawai'i cheesewood (Pittosporum hawaiiense) in Hawaii [9]. Historically there has been confusion distinguishing these two closely related species because they are morphologically very similar [10]. By use Internal Transcribed Spacer (ITS) regions of ribosomal DNA and Amplified Fragment Length Polymorphisms (AFLP), it was clearly demonstrated that $G$. citricarpa is the CBS pathogen while $G$. mangiferae (Anamorph: Phyllosticta capitalensis) is a cosmopolitan endophyte of many woody plants including 
citrus. While the taxonomy of the two species appears to be clear, the evolutionary forces allowing for co-occurrence on citrus continues to be discussed $[9,11]$.

Copper products are a mainstay of citrus disease management [12]. Since the introduction and establishment of citrus canker, caused by the bacterium Xanthomonas citri subsp. citri, both the rate and frequency of copper applications has increased substantially per season in Florida since $1995[13,14]$. The use of copper in managing citrus canker is implemented in most affected Florida citrus groves. Current management practices suggest fruit should be sprayed on a 21-day interval from $6 \mathrm{~mm}$ size to fully grown depending on the citrus variety. Studies from Brazil, South Africa, and Australia have indicated that copper can be used to manage CBS as a protectant [1517].

The frequent copper applications on citrus for disease management of citrus canker and other diseases within Florida warrants an examination on the effect of copper on isolates of the recently introduced G. citricarpa since multiple applications of fungicides containing copper are the backbone of disease management recommendations [18]. To assist in developing an understanding of CBS disease on citrus in Florida, isolates of G. citricarpa and the common saprophyte $G$. mangiferae associated with CBS were characterized using morphological and molecular methods. Additionally, in vitro assays were conducted to assess sensitivity of the isolates to copper. Finally, a field trial was conducted using commercially available copper formulation to evaluate their protective effect against fruit fall and lesion development due to CBS.

\section{Material and Methods}

\subsection{Isolation from Citrus Black Spot Infected Citrus}

Citrus fruit with CBS-typical lesions were collected from Southwest Florida during 2010 and 2011. Fruit lesions consisted of hard-spot or shot hold spots, false melanose or speckled blotch, freckle spot, and virulent spot (Figure 1). Lesions were excised using a $2.0 \mathrm{~mm}$ Harris Uni-Core Punch (Sigma-Aldrich, St. Louis, MO) and the albedo removed. A total of 15 lesions were placed into a $1.5 \mathrm{ml}$ micro-centrifuge tube containing $1 \mathrm{ml}$ of $70 \%$ ethanol for $30 \mathrm{~s}$ with gentle agitation. Ethanol was removed by pipetting and tissue were further disinfested in $1 \mathrm{ml}$ of $1 \% \mathrm{NaOCl}_{2}(\mathrm{v} / \mathrm{v})$ for 2 min with gentle agitation. Sodium hypochlorite was removed by pipetting and lesions were rinsed three times in $1 \mathrm{ml}$ sterilized distilled water. Lesions were dried in petri dishes containing sterile filter paper in a biosafety cabinet. Dried lesions were split and one half was used for isolation and the other half for DNA extraction. Lesions were placed on the surface or imbedded in non-amended Potato Dextrose Agar (PDA) and incubated under ambient temperature for 7 days (ambient lighting conditions). Fungi with morphology characteristic of Guignardia were sub-cultured. Subcultures were transferred by hyphal-tip to select for individuals by transferring to new PDA plates then maintained under ambient laboratory conditions. Isolates recovered are listed in Table $\mathbf{1 .}$

\subsection{Phenotypic and Molecular Characterization}

All isolates in Table 1 were assessed for colony morphology on PDA and oatmeal agar (OA) [9]. Plugs of actively growing mycelia were transferred to $\mathrm{OA}$ and assessed for pigmentation in the media after 4 days growth in the dark at $25^{\circ} \mathrm{C}$. Production of a yellow pigment in $\mathrm{OA}$ is considered a hallmark for distinguishing between the pathogenic fungi G. citricarpa (yellow halo) and the saprophyte G. mangiferae (no yellow halo).

Molecular characterization was performed from genomic DNA extracted from fruit lesions or from mycelial mats grown in Potato Dextrose Broth (PDB) for 7 days. DNA was extracted from lyophilized tissue using the DNeasy Plant Mini Kit (Qiagen Inc., Valencia, CA).

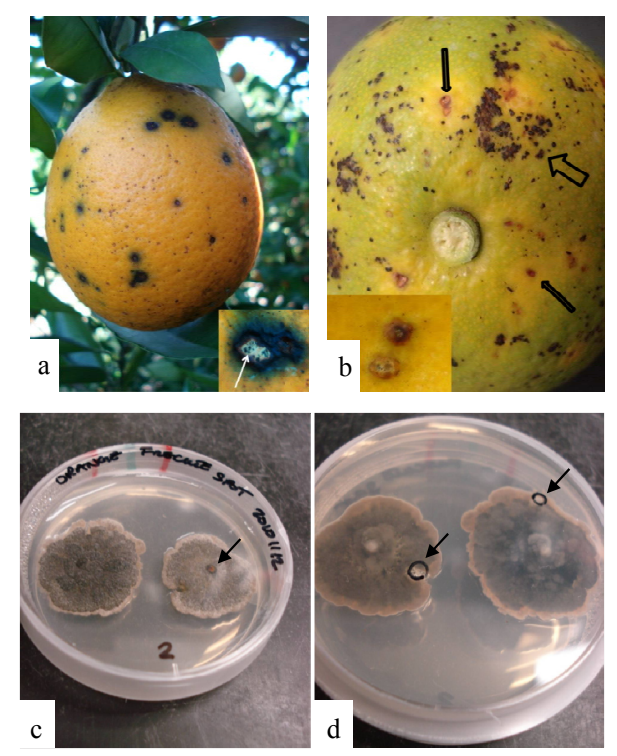

Figure 1. Citrus black spot lesions, caused by Guignardia citricarpa on sweet orange (Citrus sinensis). (a) Sweet orange fruit with hard spot type lesions, (Inset) Hard spot lesions with pycnidia present. (b) Sweet orange with false melanose (large arrow) and early virulent spots (small arrow and Inset). (c) Guignardia-like colonies growing out of 2 $\mathrm{mm}$ plugs taken from freckle spot lesions. Note citrus plug in the center of each colony (arrow). (d) Underside of platenote fungus appears to be "eating" into the agar-typical of Guignardia spp. Black circle with arrows represent where mycelial plug was taken for fungal isolate clean-up. 
Table 1. List of Guignardia spp. isolates obtained from Citrus sinensis fruits in Florida and their characteristics included in the study.

\begin{tabular}{|c|c|c|c|c|c|}
\hline $\begin{array}{c}\text { Year } \\
\text { Isolated }\end{array}$ & $\begin{array}{c}\text { Isolate } \\
\text { ID }\end{array}$ & $\begin{array}{c}\text { ITS } \\
\text { Sequence }\end{array}$ & $\begin{array}{c}\text { GCN/ } \\
\text { GCMN }\end{array}$ & $\begin{array}{c}\text { Yellow } \\
\text { Pigment on } \\
\text { OA }\end{array}$ & Identity \\
\hline 2010 & FLGC1 & yes & + & yes & G. citricarpa \\
\hline 2010 & FLGC2 & yes & + & yes & G. citricarpa \\
\hline 2010 & FLGM1 & yes & - & no & G. mangiferae \\
\hline 2010 & FLGC3 & no & + & - & G. citricarpa \\
\hline 2010 & FLGC4 & no & + & - & G. citricarpa \\
\hline 2010 & FLGC5 & no & + & - & G. citricarpa \\
\hline 2010 & FLGM2 & no & - & no & G. mangiferae \\
\hline 2010 & FLGC6 & no & + & - & G. citricarpa \\
\hline 2010 & FLGC7 & no & + & - & G. citricarpa \\
\hline 2010 & FLGC8 & no & + & - & G. citricarpa \\
\hline 2010 & FLGC9 & no & + & - & G. citricarpa \\
\hline 2010 & FLGC10 & no & + & - & G. citricarpa \\
\hline 2011 & FLGC11 & no & + & - & G. citricarpa \\
\hline 2011 & FLGC12 & no & + & - & G. citricarpa \\
\hline 2011 & FLGC13 & no & + & yes & G. citricarpa \\
\hline 2011 & FLGC14 & no & + & yes & G. citricarpa \\
\hline 2011 & FLGC15 & no & + & yes & G. citricarpa \\
\hline 2011 & FLGC16 & no & + & yes & G. citricarpa \\
\hline 2011 & FLGC17 & no & + & yes & G. citricarpa \\
\hline 2011 & FLGC18 & no & + & - & G. citricarpa \\
\hline 2011 & FLGM3 & no & - & no & G. mangiferae \\
\hline 2011 & FLGC19 & no & + & yes & G. citricarpa \\
\hline 2011 & FLGC20 & no & + & yes & G. citricarpa \\
\hline 2011 & FLGC21 & no & + & yes & G. citricarpa \\
\hline 2011 & FLGC22 & no & + & - & G. citricarpa \\
\hline 2011 & FLGC23 & no & + & - & G. citricarpa \\
\hline 2011 & FLGC24 & no & + & - & G. citricarpa \\
\hline 2011 & FLGC25 & no & + & yes & G. citricarpa \\
\hline 2011 & FLGC26 & no & + & yes & G. citricarpa \\
\hline 2011 & FLGC27 & no & $\mathrm{n} / \mathrm{a}$ & yes & G. citricarpa \\
\hline 2011 & FLGC28 & no & + & yes & G. citricarpa \\
\hline 2011 & FLGC29 & no & + & yes & G. citricarpa \\
\hline 2011 & FLGC30 & no & + & yes & G. citricarpa \\
\hline 2011 & FLGM4 & no & - & no & G. mangiferae \\
\hline 2011 & FLGC31 & no & $\mathrm{n} / \mathrm{a}$ & yes & G. citricarpa \\
\hline 2011 & FLGC32 & no & + & yes & G. citricarpa \\
\hline 2011 & FLGC33 & yes & + & - & G. citricarpa \\
\hline 2011 & FLGC34 & yes & + & - & G. citricarpa \\
\hline 2011 & FLGC35 & yes & + & - & G. citricarpa \\
\hline 2011 & FLGC36 & yes & + & - & G. citricarpa \\
\hline 2011 & FLGC37 & yes & + & - & G. citricarpa \\
\hline 2011 & FLGC38 & yes & + & - & G. citricarpa \\
\hline 2011 & FLGC39 & yes & + & - & G. citricarpa \\
\hline 2011 & FLGC40 & yes & + & - & G. citricarpa \\
\hline
\end{tabular}

Genomic DNAs were subjected to PCR using species specific primers CITRI1 and ITS4 for G. citricarpa and CAMEL2 and ITS4 for G. mangiferae [19]. Amplification was confirmed by agarose electrophoresis.

PCR products for the ITS region obtained using primer pairs CITRI1/ITS4 and CAMEL2/ITS4 were purified using QIAquick ${ }^{\circledR}$ PCR Purification Kit (Qiagen, USA). Samples were sequenced bi-directionally using the same primers for amplification on an ABI 3130 at UF's Interdisciplinary Center for Biotechnology Research (ICBR). Individual sequence trace data were scored for quality using the PHRAP algorithm and then manually edited in CodonCode Aligner (CodonCode Corporation, USA). The resulting contigs were compared with publicly available data through NCBI. Isolates confirmed as G. citricarpa and G. mangiferae by both morphology and ITS data were used as controls for identification of further Guignardia isolates. Isolates were further characterized by subjecting genomic DNAs to PCR with the GCN/ GCMN and GMN/GCMN primer pairs as described previously [20].

\subsection{In Vitro Copper Assays}

A subset of $G$. citricarpa and $G$. mangiferae isolates were used to assess sensitivity to copper. In all studies, growth was assessed in triplicate on copper-amended PDA media (copper (II) sulfate pentahydrate, Fisher Scientific, USA). In the preliminary trial (Trial 1), radial growth was assessed on PDA medium amended with 0 , 50 and $500 \mu \mathrm{g} \cdot \mathrm{ml}^{-1}$ of copper. Subsequently, in trials 2 and 3, radial growth was evaluated on PDA amended with 0 and $500 \mu \mathrm{g} \cdot \mathrm{ml}^{-1}$ copper. Copper assays were conducted at $25^{\circ} \mathrm{C}$ in the dark from 26 to 59 days. Colony diameter was measured in two directions at perpendicular to one another, repeatedly (approximately every 3 days within the first 21 days and weekly thereafter) over the study period. In trial 1, percent growth of each isolate was assessed on Day 7 and 21, and calculated as average diameter of colony on copper-amended medium divided by the average diameter of the colony on control medium.

\subsection{Copper Field Trial}

The trial was conducted in a commercial grove in Southwest Florida that was identified with Citrus Black Spot (CBS) in 2010. Citrus was planted at a spacing of $3.7 \mathrm{~m}$ $\times 6.9 \mathrm{~m}$ and consisted of 23-year-old "Valencia" on Swindle rootstock. In spring 2011, sites within the grove were scouted and rows of "Valencia" trees were identified that had a fairly even distribution of fruit with symptoms of CBS. Plots consisted of five trees; three central trees from which data was collected and a buffer 
tree on either side per plot. There were four replications per treatment arranged in a randomized complete block design. Fungicide applications were carried out with a tractor mounted speed sprayer with a spray volume of $1169 \mathrm{~L} \cdot \mathrm{ha}^{-1}$. There were sixteen treatments of which four will be presented for the purposes of this manuscript. Treatments were Kocide ${ }^{\circledR} 3000$ DF (copper hydroxide, $2.5 \mathrm{lb} / \mathrm{A}$; T1), Kocide ${ }^{\circledR} 3000$ DF $2.5 \mathrm{lb} / \mathrm{A}$ plus an adjuvant to enhance the rain fastness of the copper (T2) and Magna-Bon ${ }^{\circledR}$, (copper sulfate pentahydrate; 100 ppm; T3). Controls (T0) received no applications of fungicides. Fungicides applications were initiated in May 2011 after fruits were harvested and were applied according to KAC Agricultural Research, Inc. standard protocol on a $23.3 \pm$ 4.7 day intervals for a total of seven sprays (18 May; 8 Jun; 5 July; 21 July; 15 Aug; 13 Sept and 5 Oct of 2010). Outcome parameters were measured within the three middle trees of each plot. Outcome parameters were

1) Late mid-season fruit fall (the number of fruit raked from under the canopy for each plot) and number of fallen fruit with and without CBS lesions (December 21, 2011);

2) Number of fruit with and without CBS lesions in a square meter. Here all the fruit within a one-meter sampling square held against the tree canopy was counted and counts of fruits with and without CBS symptoms noted. Counts were taken on opposite sides of the trees (February 15, 2012);

3) Number of fruits with and without CBS lesion on 100 picked fruit and disease severity (March 14, 2012). Assessment of the severity of disease was measured on a scale of $0-5$ with 0 being no lesions and $5=100 \%$ CBS lesions;

4) End-of-season fruit fall, a final rating of fruit raked from beneath trees with and without CBS lesions (March 21, 2012).

\subsection{Statistical Analysis of Copper Assays}

In trial 1 , size of colony was analyzed using a general linear model with treatment (control, $50 \mu \mathrm{g} \cdot \mathrm{ml}^{-1}$ copper, and $500 \mu \mathrm{g} \cdot \mathrm{ml}^{-1}$ copper), isolate ID, and days post-plate inoculation as fixed effects. Day since inoculation was treated as continuous. Days post inoculation was square root transformed to account for the non-linear relationship of colony size and time. The data were repeated observations on the same plates during the experiment, hence non-independent residual covariance terms in the model were modeled using a power covariance structure because Akaike's information criterion (AICC) indicated that this was the best covariance matrix among several choices (independent, unstructured, compound symmetry, and power).

A subsample from trials 1, 2, and 3 was analyzed that excluded G. mangiferae and the $50 \mu \mathrm{g} \cdot \mathrm{ml}^{-1}$ copper treatments. Size of colony was analyzed using a general linear model with treatment (control or $500 \mu \mathrm{g} \cdot \mathrm{ml}^{-1}$ copper), isolate ID, and days post plate inoculation as fixed effects. Day since inoculation was treated as continuous and interactions of treatment, isolate ID, and days since inoculation were included. Only those isolates common to all three trials were included. Trial ID $(1,2$, or 3$)$ and the interaction of trial with the fixed effects were included as random effects to control for experimental replication effects Days post inoculation was square root transformed to account for the non-linear relationship of colony size and time. Since the data were repeated observations on the same plates during the experiment, non-independent residual covariance terms modeled using a power covariance structure based on Akaike's information criterion (AICC). Finally, we allowed the residual covariance terms to differ by trial ID (trial 1 had significantly lower variance than the other two trials). Statistically insignificant interactions and main effects were removed hierarchically until only the significant effects $(p<0.05)$ remained.

\subsection{Statistical Analysis of Field Trial}

For the field trial data, we ran two models. The first model tested the effect of treatment and date on total fruit fall using a generalized linear mixed model. Block and plot within block were random effects; treatment, date and their interaction were fixed effects. Only two dates were used: December 2011 and March 2012. Distribution of total fruit fall was a negative binomial. The interaction of treatment and date was not significant $(\mathrm{p}=0.0931)$ and was removed from the model. Pairwise tests of main effects means for treatment and for date were performed using the Tukey-Kramer method to control for experiment-wise error rate.

The second model tested the effect of treatment and date/method on the proportion of observed fruit with black spots again using a generalized linear mixed model with block and plot as random effects. In this analysis, there were four date and collection method combinations (December + fallen under tree, February + square meter of tree, March + picked fruit, and March + fallen under tree) that are not in a factorial arrangement and so were treated as four levels of a single main effect. Here, the number of fruit with black spots was assumed to binomially distributed with the number of trials set to the number of observed fruit. The interaction of treatment and date/method was not significant $(p=0.9334)$ and was removed from the model before testing main effects. Pairwise tests of main effects means for treatment and for date/method were performed using the Tukey-Kramer 
method to control for experiment-wise error rate.

\section{Results}

Isolates obtained from $2 \mathrm{~mm}$ plugs taken from a variety of CBS lesion types yielded Guignardia spp. as well as other fungal colonies. Rarely, only Guignardia-appearing colonies were obtained from $2 \mathrm{~mm}$ plugs (Figures 1(c) and (d)). The most common fungus co-isolated with Guignardia spp. was Colletotrichum gloeosporioides was based on fungal morphology and ITS sequencing (data not shown). On OA, all isolates tested with the exception of isolates FLGM1, FLGM2, FLGM3, and FLGM4 produced yellow pigment.

DNA samples collected from fruit and isolated fungi with morphology similar to Guignardia spp. were confirmed to be that of G. citricarpa in all but four which were confirmed to be G. mangiferae. Using primers CITRI1/ITS4 yielded a band $\sim 580$ bp which is diagnostic for G. citricarpa [19]. With the CAMEL2/ITS4 primer pair a band $\sim 430$ bp was amplified only with $G$. mangiferae and not G. citricarpa.

A total of 21 rDNA ITS sequence data for 11 suspected G. citricarpa isolates and ten fruit lesions from 2010 were analyzed. A single monomorphic contig was assembled from the 21 isolates and a NCBI BLAST search revealed a $100 \%$ identity to Guignardia citricarpa sequences including JN791654 and HQ008221.

In all the copper assay trials, there was a significant effect of days post inoculation on size of colony measured in $\mathrm{mm}(\mathrm{p}<0.0001)$, as time progressed there was an increase in radial growth which differed by treatment and in some cases by isolate. In trial 1, there was a three way interaction between days post inoculation, treatment, and isolate on radial growth $(\mathrm{p}<0.05)$. Isolates grown on non-amended media grew faster than those grown in media amended with copper $\left(50 \mu \mathrm{g} \cdot \mathrm{ml}^{-1}\right.$ and $500 \mu \mathrm{g} \cdot \mathrm{ml}^{-1}$ copper (II) sulfate pentahydrate). Overall these differences were significant $(p<0.05)$ for most isolates with greatest growth inhibition occurring on media amended with $500 \mu \mathrm{g} \cdot \mathrm{ml}^{-1}$ copper (Table 2). Isolates FLGM04 showed no significant differences among the three treatments $(p>0.10)$ and FLGM03 showed significant difference in growth on media amended with $500 \mu \mathrm{g} \cdot \mathrm{ml}^{-1}$ copper (Table 2).

The subset of isolates analyzed across trials 1,2 and 3 consisted of isolates FLGC1, FLGC2, FLGC12, FLGC13, FLGC19, FLGC35, FLGC36 and FLGC37. These G. citricarpa isolates were significantly affected by copper $\left(500 \mu \mathrm{g} \cdot \mathrm{ml}^{-1}\right.$ copper; $\mathrm{p}<0.0001$; Figure 2) but did not differ in their response over time to treatment. That is, the main effect and all interactions with other fixed effects of isolate were not statistically significant ( $p>0.10$ for all F-tests).
Table 2. Trial 1: Effect of copper vs. no copper on radial growth of Guignardia spp. isolated from citrus sinensis fruits in Florida.

\begin{tabular}{|c|c|c|c|c|c|}
\hline Isolate ID & Estimate & $\begin{array}{c}\text { Standard } \\
\text { error }\end{array}$ & DF & t Value & $\operatorname{Pr}>|t|$ \\
\hline \multicolumn{6}{|c|}{$\begin{array}{l}50 \mu \mathrm{g} \cdot \mathrm{ml}^{-1} \text { copper } \\
\text { vs. No copper }\end{array}$} \\
\hline \multicolumn{6}{|c|}{ G. citricarpa } \\
\hline FLGC1 & -4.5161 & 2.1270 & 90.14 & -2.12 & 0.0365 \\
\hline FLGC2 & -6.4266 & 2.0827 & 83.82 & -3.09 & 0.0028 \\
\hline FLGC12 & -3.592 & 2.0827 & 83.82 & -1.72 & 0.0883 \\
\hline FLGC13 & -7.3093 & 2.0827 & 83.82 & -3.51 & 0.0007 \\
\hline FLGC14 & -4.5231 & 2.0827 & 83.82 & -2.17 & 0.0327 \\
\hline FLGC19 & -1.1472 & 2.0827 & 83.82 & -0.55 & $0.5832^{*}$ \\
\hline FLGC21 & -7.6234 & 2.0827 & 83.82 & -3.66 & 0.0004 \\
\hline FLGC22 & -8.1372 & 2.0827 & 83.82 & -3.91 & 0.0002 \\
\hline FLGC23 & -9.5567 & 2.0827 & 83.82 & -4.59 & $<0.0001$ \\
\hline FLGC35 & -3.1567 & 2.0827 & 83.82 & -1.52 & $0.1334^{*}$ \\
\hline FLGC36 & -4.4139 & 2.0827 & 83.82 & -2.12 & 0.037 \\
\hline FLGC38 & -9.3772 & 2.0827 & 83.82 & -4.50 & $<0.0001$ \\
\hline \multicolumn{6}{|c|}{ G. mangiferae } \\
\hline FLGM3 & 2.8614 & 2.0827 & 83.82 & 1.37 & $0.1731^{*}$ \\
\hline FLGM4 & -1.0407 & 2.0827 & 83.82 & -0.5 & $0.6186^{*}$ \\
\hline \multicolumn{6}{|c|}{$\begin{array}{l}500 \mu \mathrm{g} \cdot \mathrm{ml}^{-1} \text { copper } \\
\text { vs. No copper }\end{array}$} \\
\hline \multicolumn{6}{|c|}{ G. citricarpa } \\
\hline FLGC1 & -18.6940 & 2.0915 & 85.21 & -8.94 & $<0.0001$ \\
\hline FLGC2 & -18.6227 & 2.0827 & 83.82 & -8.94 & $<0.001$ \\
\hline FLGC12 & -16.8936 & 2.0827 & 83.82 & -8.11 & $<0.0001$ \\
\hline FLGC13 & -20.1928 & 2.0827 & 83.82 & -9.70 & $<0.0001$ \\
\hline FLGC14 & -19.9295 & 2.0827 & 83.82 & -9.57 & $<0.0001$ \\
\hline FLGC19 & -14.7049 & 2.0827 & 83.82 & -7.06 & $<0.0001$ \\
\hline FLGC21 & -16.6251 & 2.0937 & 85.59 & -7.94 & $<0.0001$ \\
\hline FLGC22 & -18.9647 & 2.0851 & 84.20 & -9.10 & $<0.0001$ \\
\hline FLGC23 & -19.3102 & 2.0827 & 83.82 & -9.27 & $<0.0001$ \\
\hline FLGC35 & -15.4172 & 2.0827 & 83.82 & -7.40 & $<0.0001$ \\
\hline FLGC36 & -16.7836 & 2.0885 & 84.75 & -8.04 & $<0.0001$ \\
\hline FLGC38 & -16.0636 & 2.0851 & 84.20 & -7.7 & $<0.0001$ \\
\hline \multicolumn{6}{|c|}{ G. mangiferae } \\
\hline FLGM3 & 4.4289 & 2.0827 & 83.82 & 2.13 & 0.0364 \\
\hline FLGM4 & -0.3435 & 2.0827 & 83.82 & -0.16 & $0.8694^{*}$ \\
\hline
\end{tabular}

“"” Indicates isolates whose radial growth was not significantly affect by the addition of $50 \mu \mathrm{g} \cdot \mathrm{ml}^{-1}$ and $/$ or $500 \mu \mathrm{g} \cdot \mathrm{ml}^{-1}$ copper; $\mathrm{p}>0.1$.

\section{A Field Trial}

There was no effect of date $(p=0.4000)$ or treatment ( $p$ $=0.0798$ ) on the number of fallen fruit (Table 3). On the 
other hand, both treatment $(p=0.0323)$ and date/method $(p<0.0001)$ were significant (Tables 4 and 5) effects on the proportion of observed fruit with black spots. Pairwise comparisons indicated that the proportion in $\mathrm{T} 2$ (Kocide ${ }^{\circledR} 3000$ DF $2.5 \mathrm{lb} / \mathrm{A}+$ adjuvant) differed from that in T0 (control) $(\mathrm{p}=0.0475)$ but the proportions in T0 (control), T1 (Kocide ${ }^{\circledR} 3000$ DF; copper hydroxide, $2.5 \mathrm{lb} / \mathrm{A}$ ), and T3 (Magna-Bon ${ }^{\circledR}$, copper sulfate pentahydrate; $100 \mathrm{ppm}$ ) did not differ from each other. The proportion of fruit with black spots observed in March on fallen fruit differed from all of the other date/method combinations $(\mathrm{p}<0.0001$ for December + fallen and February+ square meter of tree; $p=0.0004$ for March + sampled fruit) but the other three date/method combinations did not differ significantly.

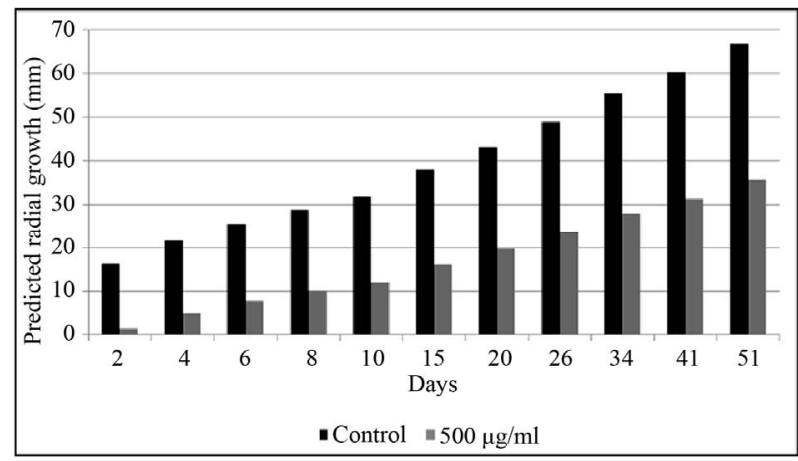

Figure 2. Trial 1, 2 and 3. Predicted radial growth (mm) curves of Guignardia citricarpa isolates based on statistical analysis of colony diameter followed for 51 days on nonamended media and media amended with $500 \mathrm{ug} \cdot \mathrm{ml}^{-1}$ copper sulfate.

Table 3. Estimated means and standard errors of the means for the 8 combinations of date and treatment on the number of fallen fruit.

\begin{tabular}{|c|c|c|c|}
\hline Date & Treatment & Mean & $\begin{array}{l}\text { Standard } \\
\text { Error Mean }\end{array}$ \\
\hline Dec & Control & 56.4222 & 12.9032 \\
\hline Mar & Control & 38.7960 & 9.1787 \\
\hline Dec & $\begin{array}{c}\mathrm{T} 1 \text { (Kocide }^{\circledR} 3000 \mathrm{DF} \text {; copper } \\
\text { hydroxide, } 2.5 \mathrm{lb} / \mathrm{A})\end{array}$ & 58.1469 & 13.2945 \\
\hline Mar & $\begin{array}{c}\mathrm{T} 1 \text { (Kocide }^{\circledR} 3000 \mathrm{DF} \text {; copper } \\
\text { hydroxide, } 2.5 \mathrm{lb} / \mathrm{A})\end{array}$ & 72.0887 & 16.5307 \\
\hline Dec & $\begin{array}{l}\text { T3 } \text { (Magna-Bon }^{\circledR}, \text { copper sulfate } \\
\text { pentahydrate; } 100 \text { ppm) }\end{array}$ & 61.9653 & 14.1130 \\
\hline Mar & $\begin{array}{l}\text { T3 } \text { (Magna-Bon }^{\circledR}, \text { copper sulfate } \\
\text { pentahydrate; } 100 \text { ppm) }\end{array}$ & 58.0358 & 13.5365 \\
\hline Dec & $\begin{array}{l}\mathrm{T} 2\left(\text { Kocide }^{\circledR} 3000 \mathrm{DF}\right. \\
2.5 \mathrm{lb} / \mathrm{A}+\text { adjuvant })\end{array}$ & 58.5109 & 13.3668 \\
\hline Mar & $\begin{array}{l}\mathrm{T} 2\left(\text { Kocide }^{\circledR} 3000 \mathrm{DF}\right. \\
2.5 \mathrm{lb} / \mathrm{A}+\text { adjuvant })\end{array}$ & 127.3100 & 29.0554 \\
\hline
\end{tabular}

Table 4. Estimated means and standard errors of the means for treatment on the proportion of fruit observed with black spot symptoms.

\begin{tabular}{|c|c|c|c|}
\hline Treatment & Mean & $\begin{array}{l}\text { Standard } \\
\text { Error Mean }\end{array}$ & Tukey-Kramer ${ }^{*}$ \\
\hline Control & 0.4143 & 0.08219 & a \\
\hline $\begin{array}{c}\mathrm{T} 1\left(\text { Kocide }^{\circledR} 3000 \mathrm{DF} ;\right. \\
\text { copper hydroxide, } 2.5 \mathrm{lb} / \mathrm{A})\end{array}$ & 0.5970 & 0.08087 & $\mathrm{a}$ \\
\hline $\begin{array}{c}\text { T3 }\left(\text { Magna-Bon }{ }^{\circledR} \text {, copper }\right. \\
\text { sulfate pentahydrate; } 100 \mathrm{ppm} \text { ) }\end{array}$ & 0.4531 & 0.08351 & $\mathrm{a}$ \\
\hline $\begin{array}{c}\text { T2 }\left(\text { Kocide }^{\circledR} 3000 \mathrm{DF}\right. \\
2.5 \mathrm{lb} / \mathrm{A}+\text { adjuvant })\end{array}$ & 0.6680 & 0.07480 & $\mathrm{~b}$ \\
\hline
\end{tabular}

“"” Means with the same letter are not significantly difference from each other; Tukey-Kramer test, $\mathrm{p}<0.05$.

Table 5. Estimated means and standard errors of the means for date/method on the proportion of fruit observed with black spot symptoms.

\begin{tabular}{cccc}
\hline Date/Method & Mean & $\begin{array}{c}\text { Standard } \\
\text { Error Mean }\end{array}$ & Tukey-Kramer \\
\hline $\begin{array}{c}\text { December + fallen } \\
\text { under tre }{ }^{\mathrm{a}}\end{array}$ & 0.2979 & 0.07057 & $\mathrm{a}$ \\
$\begin{array}{c}\text { February + square } \\
\text { meter of tree }\end{array}$ & 0.3666 & 0.07759 & $\mathrm{a}$ \\
$\begin{array}{c}\text { March + fallen } \\
\text { under tree }\end{array}$ & 0.8616 & 0.04126 & $\mathrm{~b}$ \\
March + picked fruit $^{\mathrm{d}}$ & 0.5331 & 0.08266 & $\mathrm{a}$ \\
\hline
\end{tabular}

“" Means with the same letter are not significantly difference from each other; Tukey-Kramer test, $\mathrm{P}<0.05$. ${ }^{\mathrm{a}}$ fruit raked from under the canopy on December 21,2011 ; ${ }^{b}$ fruit counted within a one-meter sampling square held to tree canopy on February 15,2012 ; $^{\text {c }}$ fruit raked from under the canopy on March 21, 2012; ${ }^{\mathrm{d}} 100$ fruit picked on March 14, 2012.

\section{Discussion}

The use of copper fungicides to reduce CBS symptoms on fruit has been used successfully in field trials in Australia, South America and South Africa [2,15,17,21,22]. However, this was not the case in this study, where copper did not reduce the proportion of fruit with black spot symptoms measured either on fallen fruits, fruits within one-meter square of the canopy or in 100 picked fruit, measured throughout the growing season. Conversely, reducing the number of fruit with lesions at the time of harvest does not necessarily equate to less fruit with the potential of expressing lesions post-harvest [23], and perhaps this end-point should be considered the best measurement of fungicide performance. Seberry and colleagues (1967) demonstrated that pre-harvest application of copper had no effect on CBS symptoms after harvest. This may indicate that although copper may reduce the growth rate of G. citricarpa, as shown in the in vitro assays, copper is not capable of inhibiting the expression of symptoms once the fruit is infected. This concept is re-enforced in the field trail by the lack of ef- 
fect of copper on the number of fallen fruit exhibiting black spot symptoms, with the exception of T2 Kocide $^{\mathbb{B}}$ $3000 \mathrm{DF} 2.5 \mathrm{lb} / \mathrm{A}+$ adjuvant) where an increase in the mean portion of fruit with black spot symptoms was seen.

The latter comment leads to a conundrum - Why did Kocide $^{\circledR} 3000$ DF $2.5 \mathrm{lb} / \mathrm{A}+$ adjuvant result in a higher mean portion of fruit with black spot symptoms than the control or Kocide ${ }^{\circledR} 3000$ DF 2.5 lb/A alone? This may have been due to the properties of the adjuvant, its ability to enhance the rain fastness of copper. During a rain or irrigation event, conidia are release and carried in rain- or irrigation-water and distributed to susceptible citrus tissues. During heavy rains or irrigation events it is more likely that spores will be washed out of the canopy and to the ground. However, the adjuvant may have enhanced the ability of conidia to stick to susceptible citrus tissues following fungicide-adjuvant application and also limiting washout during heavy rain or irrigation events. It is not known whether the adjuvant itself directly enhances the germinating and penetrating ability of G. citricarpa spores and this also requires further investigation. Further, the method of application of fungicide may play a role in the dispersal of conidia throughout the tree and ascospores from the leaf litter into the tree canopy. This phenomenon has yet to be investigated under Florida's field and management conditions. There is evidence to suggest that the inhibitory effect of $50 \mu \mathrm{g} \cdot \mathrm{ml}^{-1}$ copper on radial growth of $G$. citricarpa varies between isolates (Table 2) and thus within the field population of G. citricarpa. Radial growth for G. citricarpa isolates FLGC 19 and FLGC35 on media amended with $50 \mathrm{ug} \cdot \mathrm{ml}^{-1}$ copper were not statistically different from radial growth on non-amended media $(p>0.10)$. This would suggest that fruit and leaves having less that $50 \mu \mathrm{g} \cdot \mathrm{ml}^{-1}$ (approximately $4.2 \mu \mathrm{g} \cdot \mathrm{cm}^{-2}$ ) copper available on their surfaces will not limit the growth of some isolates of $G$. citricarpa. Additionally, the Citrus Copper Application Scheduler (http://www.agroclimate.org/tools/cudecay/; [24]) suggests that copper sprays be re-applied when estimated $\mathrm{Cu}$ residues are between 0.25 and $0.5 \mu \mathrm{g} \cdot \mathrm{cm}^{-2}$ (approximately $3-6 \mu \mathrm{g} \cdot \mathrm{ml}^{-1}$ in solution), well below our 50 $\mu \mathrm{g} \cdot \mathrm{ml}^{-1}$. Although these values are based on germination of Diaporthe citri, the causal agent of melanose, it is not known whether these levels will have the same effect on germination of conidia for G. citricarpa isolates found in Florida. Albrigo et al. (2005) has proposed that as little as $1 \mu \mathrm{g} \cdot \mathrm{ml}^{-1}$ available copper will prevent spore germination of $D$. citri Wolf, and 1 to $2 \mu \mathrm{g} \cdot \mathrm{ml}^{-1} \mathrm{Cu}$ is enough to sup- press growth of some fungi and bacteria [25]. The lack of a significant reduction in radial growth by $50 \mu \mathrm{g} \cdot \mathrm{ml}^{-1}$ copper by some isolates (FLGC19 and FLGC35) may indicate that Florida G. citricarpa isolates have the potential to develop insensitivity to copper as seen with the uninhibited growth of G. mangiferae at 50 and $500 \mu \mathrm{g} \cdot \mathrm{ml}^{-1}$ copper.

Schutte et al. (1997) demonstrated that repeated application of some copper formulations causes rind stippling on Valencia oranges. The concentration of copper which effectively reduced G. citricarpa growth was 500 $\mu \mathrm{g} \cdot \mathrm{ml}^{-1}$ in this study and was 95 times the concentration of copper residue washed from fruits subjected to the highest application rate (applied at $1.70 \mathrm{~g}$ a.i./liter of water) of copper formulation in the study by Schutte et al. (1997). In addition, the effective concentration of 500 $\mu \mathrm{g} \cdot \mathrm{ml}^{-1}$ was eight times that of copper residue extracted from dry peel. Application of the copper formulation with the above residual copper on the surface of the fruit and within the peel resulted in $68 \%$ of fruit exhibiting rind stippling [15].

Insensitivity to copper by G. mangiferae may have developed due to selective pressures caused by the continuous exposure of G. mangiferae to copper in citrus groves since the introduction of copper as a means to correct copper deficiency and later in controlling fungal diseases [13]. Interestingly, isolate FLGM3 was sensitive only to $500 \mu \mathrm{g} \cdot \mathrm{ml}^{-1}$ copper, compared to isolate FLGM4. Although only two G. mangiferae isolates were tested, these results indicate that it may possess a spectrum of sensitivities to copper. Fungi resist the detrimental effect of heavy metals such as copper by a variety of mechanisms. These may be active or passive mechanisms and include exclusion by permeability barriers (increased production of melanin in response to heavy metals strengthening the cell and changes in cell wall structure and components) [26], passive entrapment and subsequent binding in cellular structures such as copper binding in fungal cell-wall [26], extracellular chelation or precipitation by secreted metabolites and active sequestration of metal ions through intracellular complexing with metallothioneins and phytochelatins. Other active processes include altered uptake of copper. Only the metallothionein chelation mechanism has been approached with molecular detail [27-29]. If this is the case, it would be well worth investigating the effect of copper on $G$. mangiferae isolates from historically copper free area, the mechanism(s) by with G. mangiferae resists copper and if these pathways exist in its close relative G. citricarpa.

\section{Acknowledgements}

We extend our appreciation to the management and crew of the commercial grove; Henry D. Yonce and Carol Brooks of KAC Agricultural Research Inc., for their aid in conducting the field trials and to Jacob Collins and Chad Grannis for their assistance with culture mainte- 
nance.

\section{REFERENCES}

[1] T. B. Kiely, "Preliminary Studies on Guignardia citricarpa, n sp: The Ascigerous Stage of Phoma citricarpa Mcalp and Its Relation to Black Spot of Citrus," Proceedings of the Linnean Society of New South Wales, Vol. 73, No. 5-6, 1948, pp. 249-292.

[2] J. M. Kotze, "Epidemiology and Control of Citrus Black Spot in South-Africa," Plant Disease, Vol. 65, No. 12, 1981, pp. 945-950. doi:10.1094/PD-65-945

[3] A. H. Benson, "Black Spot of the Orange," Agricultural Gazette of New South Wales, Vol. 6, No. 4, 1895, pp. 249-252.

[4] K. R. Everett and J. Rees-George, "Reclassification of an Isolate of Guignardia citricarpa from New Zealand as Guignardia mangiferae by Sequence Analysis," Plant Pathology, Vol. 55, No. 2, 2006, pp. 194-199. doi:10.1111/j.1365-3059.2006.01334.x

[5] R. Reeder, P. L. Kelly and R. Harling, "First Confirmed Report of Citrus Black Spot Caused by Guignardia citricarpa on Sweet Oranges (Citrus sinensis) in Uganda," Plant Pathology, Vol. 58, No. 2, 2009, p. 399. doi:10.1111/j.1365-3059.2008.01966.x

[6] T. S. Schubert, M. M. Dewdney, N. A. Peres, M. E. Palm, A. Jeyaprakash, B. Sutton, et al., "First Report of Guignardia citricarpa Associated with Citrus Black Spot on Sweet Orange (Citrus sinensis) in North America," Plant Disease, Vol. 96, No. 8, 2012, p. 1225. doi:10.1094/PDIS-01-12-0101-PDN

[7] Agricultural Marketing Resource Center, "Citrus Profile," 2010.

http://www.agmrc.org/commodities__products/fruits/citru $\mathrm{s} /$ citrus profile.cfm

[8] R. T. McMillan, “Guignardia citricarpa a Cause of Black Spot on Mango Foliage in Florida," Journal of Phytopathology, Vol. 117, No. 3, 1986, pp. 260-264. doi:10.1111/j.1439-0434.1986.tb00940.x

[9] R. P. Baayen, P. J. M. Bonants, G. Verkley, G. C. Carroll, H. A. van der Aa, M. de Weerdt, et al., "Nonpathogenic Isolates of the Citrus Black Spot Fungus, Guignardia citricarpa, Identified as a Cosmopolitan Endophyte of Woody Plants, G. mangiferae (Phyllosticta capitalensis)," Phytopathology, Vol. 92, No. 5, 2002, pp. 464-477. doi:10.1094/PHYTO.2002.92.5.464

[10] K. R. Everett and J. Rees-George, "Species-Specific PCR Primers for Guignardia citricarpa and Guignardia mangiferae," New Zealand Plant Protection, Vol. 59, No. 2006, pp. 141-145.

[11] R. B. Baldassari, E. Wickert and A. de Goes, "Pathogenicity, Colony Morphology and Diversity of Isolates of Guignardia citricarpa and G. mangiferae Isolated from Citrus spp.," European Journal of Plant Pathology, Vol. 120, No. 2, 2008, pp. 103-110. doi:10.1007/s10658-007-9182-0

[12] R. P. Leite and S. K. Mohan, "Integrated Management of the Citrus Bacterial Canker Disease Caused by Xanthomonas campestris pv citri in the State of Parana, Brazil," Crop Protection, Vol. 9, No. 1, 1990, pp. 3-7. doi:10.1016/0261-2194(90)90038-9

[13] P. J. Driscoll, "Copper Toxicity on Florida Citrus: Why Did It Happen?" Proceedings of the Florida State Horticultural Society, Vol. 117, No. 117, 2004, pp. 124-127.

[14] J. H. Graham, T. R. Gottwald, J. Cubero and D. S. Achor, "Xanthomonas axonopodis pv. citri: Factors Affecting Successful Eradication of Citrus Canker," Molecular Plant Pathology, Vol. 5, No. 1, 2004, pp. 1-15. doi:10.1046/j.1364-3703.2004.00197.x

[15] G. C. Schutte, K. V. Beeton and J. M. Kotze, "Rind Stippling on Valencia Oranges by Copper Fungicides Used for Control of Citrus Black Spot in South Africa," Plant Disease, Vol. 81, No. 8, 1997, pp. 851-854. doi:10.1094/PDIS.1997.81.8.851

[16] A. J. Timossi, A. de Goes, K. C. Kupper, R. B. Baldassari, R. F. de Reis, A. de Goes, et al., "Influence of Temperature and Light on the Development of Guignardia citricarpa, the Causal Agent of Citrus Black Spot," Fitopatologia Brasileira, Vol. 28, No. 5, 2003, pp. 489-494. doi:10.1590/S0100-41582003000500004

[17] K. C. Kupper, W. Bettiol, A. de Goes, P. S. de Souza and J. A. M. Bellotte, "Biofertilizer for Control of Guignardia citricarpa, the Causal Agent of Citrus Black Spot," Crop Protection, Vol. 25, No. 6, 2006, pp. 569-573. doi:10.1016/j.cropro.2005.09.002

[18] M. M. Dewdney, T. S. Schubert, M. R. Estes and N. A. Peres, "2012 Florida Citrus Pest Management Guide: Citrus Black Spot," 2012 Florida Citrus Pest Management Guide, Vol. PP279, 2012, pp. 93-98.

[19] L. Meyer, G. M. Sanders, R. Jacobs and L. Korsten, “A One-Day Sensitive Method to Detect and Distinguish between the Citrus Black Spot Pathogen Guignardia citricarpa and the Endophyte Guignardia mangiferae," Plant Disease, Vol. 90, No. 1, 2006, pp. 97-101. doi:10.1094/PD-90-0097

[20] N. A. Peres, R. Harakava, G. C. Carroll, J. E. Adaskaveg and L. W. Timmer, "Comparison of Molecular Procedures for Detection and Identification of Guignardia citricarpa and G. mangiferae," Plant Disease, Vol. 91, No. 5, 2007, pp. 525-531. doi:10.1094/PDIS-91-5-0525

[21] J. P. Agostini, N. A. Peres, S. J. Mackenzie, J. E. Adaskaveg and L. W. Timmer, "Effect of Fungicides and Storage Conditions on Postharvest Development of Citrus Black Spot and Survival of Guignardia citricarpa in Fruit Tissues," Plant Disease, Vol. 90, No. 11, 2006, pp. 1419 1424. doi:10.1094/PD-90-1419

[22] E. C. Calavan, "Black Spot of Citrus," California Citrograph, Vol. 46, 1960, pp. 22-24.

[23] J. A. Seberry, D. Leggo and T. B. Kiely, "Effect of Skin Coatings on the Development of Black Spot in Stored Valencia Oranges," Australian Journal of Experimental Agriculture and Animal Husbandry, Vol. 7, No. 29, 1967, pp. 593-600. doi:10.1071/EA9670593

[24] L. G. Albrigo, H. W. Beck, L. W. Timmer and E. Stover, "Development and Testing of a Recommendation System 
to Schedule Copper Sprays for Citrus Disease Control," Journal of ASTM International (JAI), Vol. 2, No. 9, 2005, p. 12904. doi: $10.1520 /$ JAI12904

[25] O. Menkissoglu and S. E. Lindow, "Chemical Forms of Copper on Leaves in Relation to the Bactericidal Activity of Cupric Hydroxide Deposits on Plants," Phytopathology, Vol. 81, No. 10, 1991, pp. 1263-1270. doi:10.1094/Phyto-81-1263

[26] C. Cervantes and F. Gutierrezcorona, "Copper Resistance Mechanisms in Bacteria and Fungi," FEMS Microbiology Reviews, Vol. 14, No. 2, 1994, pp. 121-137. doi:10.1111/j.1574-6976.1994.tb00083.x
[27] I. S. Ross, "Some Effects of Heavy Metals on Fungal Cells," Transactions of the British Mycological Society, Vol. 64, No. 2, 1975, pp. 175-193. doi:10.1016/S0007-1536(75)80101-X

[28] G. M. Gadd, "Interactions of Fungi with Toxic Metals," New Phytology, Vol. 124, No. 1, 1993, pp. 25-60. doi:10.1111/j.1469-8137.1993.tb03796.x

[29] E. S. Hartikainen, P. Lankinen, J. Rajasarkka, H. Koponen, M. Virta, A. Hatakka, et al., "Impact of Copper and Zinc on the Growth of Saprotrophic Fungi and the Production of Extracellular Enzymes," Boreal Environment Research, Vol. 17, No. 3-4, 2012, pp. 210-218. 